\title{
Human endometrial regenerative cells alleviate carbon tetrachloride-induced acute liver injury in mice
}

\author{
Shanzheng Lu ${ }^{1,2+}$, Ganggang Shi ${ }^{1,2+}$, Xiaoxi Xu ${ }^{1,2+}$, Grace Wang ${ }^{3}$, Xu Lan ${ }^{1,2}$, Peng Sun ${ }^{4}$, Xiang Li ${ }^{1,2}$, \\ Baoren Zhang ${ }^{1,2}$, Xiangying Gu ${ }^{5}$, Thomas E. Ichim ${ }^{6}$ and Hao Wang ${ }^{1,2^{*}}$
}

\begin{abstract}
Background: The endometrial regenerative cell (ERC) is a novel type of adult mesenchymal stem cell isolated from menstrual blood. Previous studies demonstrated that ERCs possess unique immunoregulatory properties in vitro and in vivo, as well as the ability to differentiate into functional hepatocyte-like cells. For these reasons, the present study was undertaken to explore the effects of ERCs on carbon tetrachloride $\left(\mathrm{CCl}_{4}\right)$-induced acute liver injury (ALI).

Methods: An ALI model in C57BL/6 mice was induced by administration of intraperitoneal injection of $\mathrm{CCl}_{4}$. Transplanted ERCs were intravenously injected (1 million/mouse) into mice 30 min after ALI induction. Liver function, pathological and immunohistological changes, cell tracking, immune cell populations and cytokine profiles were assessed $24 \mathrm{~h}$ after the $\mathrm{CCl}_{4}$ induction.

Results: $\mathrm{ERC}$ treatment effectively decreased the $\mathrm{CCl}_{4}$-induced elevation of serum alanine aminotransferase (ALT) and aspartate aminotransferase (AST) activities and improved hepatic histopathological abnormalities compared to the untreated ALI group. Immunohistochemical staining showed that over-expression of lymphocyte antigen 6 complex, locus G (Ly6G) was markedly inhibited, whereas expression of proliferating cell nuclear antigen (PCNA) was increased after ERC treatment. Furthermore, the frequency of $\mathrm{CD} 4^{+}$and $\mathrm{CD} 8^{+} \mathrm{T}$ cell populations in the spleen was significantly down-regulated, while the percentage of splenic $\mathrm{CD} 4^{+} \mathrm{CD} 25^{+} \mathrm{FOXP} 3^{+}$regulatory $\mathrm{T}$ cells (Tregs) was obviously up-regulated after ERC treatment. Moreover, splenic dendritic cells in ERC-treated mice exhibited dramatically decreased MHC-II expression. Cell tracking studies showed that transplanted PKH26-labeled ERCs engrafted to lung, spleen and injured liver. Compared to untreated controls, mice treated with ERCs had lower levels of IL-1 $\beta$, IL-6, and TNF-a but higher level of IL-10 in both serum and liver.
\end{abstract}

Conclusions: Human ERCs protect the liver from acute injury in mice through hepatocyte proliferation promotion, as well as through anti-inflammatory and immunoregulatory effects.

Keywords: Endometrial regenerative cells, Acute liver injury, Anti-inflammatory, Immunoregulation

\section{Background}

Despite unprecedented advances made in modern medicine, acute liver diseases remain a healthcare burden. They can arise from viral infections, autoimmune

\footnotetext{
*Correspondence: hwangca272@hotmail.com

†Shanzheng Lu, Ganggang Shi and Xiaoxi Xu contributed equally to this work

1 Department of General Surgery, Tianjin Medical University General Hospital, 154 Anshan Road, Heping District, Tianjin 300052, China Full list of author information is available at the end of the article
}

disorders, ischemia, and xenobiotics such as alcohol, drugs and toxins, and can lead to severe clinical outcomes including hepatorenal syndrome, hepatic encephalopathy, severe infection, multiple organ failure, and even death [1]. To date, orthotropic liver transplantation is the most effective therapeutic option for patients suffering from severe irreversible and life-threatening liver damage; however, the limited availability of donor organs, high costs, and lifelong immunosuppressive therapy has severely restricted its clinical application [2]. Hence, 
alternative strategies for the treatment of decompensated liver diseases are required.

Recent development in stem cell-based therapeutic strategies have already garnered extensive attention and been introduced to regenerative medicine for hepatic diseases [3-5]. It has been demonstrated that infused mesenchymal stem cells (MSCs) engrafting in the liver facilitate the recovery from chemical-induced acute liver damage [6]. Moreover, MSCs possess the characteristics of immunomodulatory, anti-inflammatory and hypoimmunogenicity, and the potential of differentiating into hepatocyte-like cells. Also, MSCs can promote tissue repair by means of suppressing the local immune reaction, attenuating fibrosis and apoptosis, enhancing angiogenesis and stimulating mitosis and differentiation of tissue-intrinsic reparative cells and stem cells [7, 8]. Currently, bone marrow mesenchymal stem cells (BMMSCs) have become the focal point for cell therapy in liver regeneration $[9,10]$. However, BM-MSCs have low yield, invasive operation and decreased cell numbers that are dependent on donor age [11]. Consequently, it is imperative to identify alternative sources of stem cells with better safety and efficacy profiles.

In 2007, Meng et al. discovered a novel type of adult stem cells derived from human menstrual blood, named endometrial regenerative cells (ERCs). These cells possess a self-renewing, highly proliferative potential as well as a differentiation capacity towards diverse cell lineages in appropriate induction media, thereby overcoming the shortcomings of other conventional stem cell sources and the fear of karyotypic abnormalities during culture [12]. Furthermore, ERCs have proven to be an excellent cell source in the treatment of several experimental disease models, such as critical limb ischemia [13], ulcerative colitis [14], burn injury [15], renal ischemia reperfusion injury [16] and other dysfunctional diseases [17-19]. Moreover, it has been verified that these human cells were not rejected in a xenogeneic animal model [13]. ERCs are more readily available and non-invasive than other adult stem cells, making them a promising donor source for stem cell therapy. Recently, ERCs were found to be capable of differentiating into functional hepatocyte-like cells in vitro [20]. However, whether ERCs could simultaneously suppress inflammatory and immune responses and repair tissue damage following ALI remain obscure. Thus, the aim of this study was to explore the potential role of ERCs in alleviation of carbon tetrachloride $\left(\mathrm{CCl}_{4}\right)$-induced ALI.

\section{Methods}

Isolation and Culture of ERCs

ERCs were collected from the menstrual blood of healthy female volunteer donors (20-40 years old) using a urine cup after menstrual blood flow initiated. As previously described [12], mononuclear cells were obtained by standard Ficoll method. ERCs were then expanded from the purified mononuclear cells, which were allowed to attach in the endometrial stem cell culture medium (S-Evans Biosciences, China) overnight at $37{ }^{\circ} \mathrm{C}$ in $5 \%$ $\mathrm{CO}_{2}$. Non-adherent cells were removed by washing with phosphate-buffered saline (PBS), while adherent cells were cultured until they reached $80-90 \%$ confluence. Cells were trypsinized, sub-cultured and used for experiments during passages $4-7$.

\section{Animals}

Healthy male C57BL/6 mice (Aoyide Co., Tianjin,China) weighing $18-20 \mathrm{~g}$ and aged 6-8 weeks were housed under conventional experimental environment with $12-\mathrm{h}$ light-dark cycle in the Animal Care Facility, Tianjin General Surgery Institute. The mice had free access to commercial standard mouse diet and water until the time of the study. All experiments were conducted in accordance with the protocols following the Animal Care and Use Committee of Tianjin Medical University (China) according to the Chinese Council on Animal Care guidelines.

\section{Experimental groups}

The preparation of animal model was done as previously described [21, 22]. In brief, 18 mice were randomly assigned to the following three groups $(n=6)$. (1) Normal control group: mice first receiving intraperitoneal (i.p.) injection of corn oil were then injected with $200 \mu \mathrm{l}$ PBS intravenously $30 \mathrm{~min}$ later. (2) Untreated group: mice first receiving i.p. injection of a single dose of $\mathrm{CCl}_{4}$ (Sigma-aldrich, St Louis, United States) for induction of acute liver injury were injected $200 \mu \mathrm{l}$ PBS intravenously 30 min later. (3) ERC-treated group: mice first receiving i.p. injection of $\mathrm{CCl}_{4}$ were injected intravenously with $1 \times 10^{6}$ ERCs at passage 4 resuspended in $200 \mu \mathrm{l}$ of PBS 30 min later [23]. Mice were sacrificed $24 \mathrm{~h}$ after injection of $\mathrm{CCl}_{4}$, and blood was collected. Livers and spleens were then promptly removed for analysis or stored frozen at $-80{ }^{\circ} \mathrm{C}$.

\section{Measurement of ALT and AST}

Serum alanine aminotransferase (ALT) and aspartate aminotransferase (AST) activities were measured by standard spectrophotometric procedures using a ChemiLab ALT and AST assay kit (IVDLab Co., Ltd., Korea), respectively. Enzyme activities were shown in international unit per liter (IU/L).

\section{Histological examination}

Liver slices were made from part of the left lobes and fixed in $10 \%$ neutral buffered formalin, embedded in 
paraffin and cut into $5 \mu \mathrm{m}$ sections. Specimens were dewaxed, hydrated and stained with standard hematoxylin and eosin (H\&E) to examine morphology.

\section{Immunohistochemistry staining}

Immunohistochemistry was performed with PCNA and Ly6G antibody as described previously [24]. Briefly, the paraffin specimens were cut into $5 \mu \mathrm{m}$, followed by deparaffinization and rehydration. Endogenous peroxides were eliminated with $3 \% \mathrm{H}_{2} \mathrm{O}_{2}$, and antigen retrieval was processed by heating in microwave. Then, the sections were blocked with $5 \%$ bovine serum albumin (BSA) and incubated with anti-mouse PCNA and Ly6G (Abcam, Cambridge, MA) antibodies overnight at $4{ }^{\circ} \mathrm{C}$, respectively. Secondary labeling was achieved by goat antirabbit IgG and rabbit anti-rat IgG polyclonal antibody, separately. Horseradish peroxidase-conjugated avidin and brown-colored diaminobenzidine were used to visualize the labeling. Finally, the slides were counterstained with hematoxylin. All of stained sections were photographed using an Olympus inverted microscope (Olympus Imaging America, Center Valley, PA).

\section{Enzyme-linked immunosorbent assay}

The levels of IL-1 $\beta$, IL- 6 , TNF- $\alpha$,and IL-10 in the serum and liver samples taken from mice $24 \mathrm{~h}$ after $\mathrm{CCl}_{4}$ challenge were measured by ELISA kit (eBiosciences, San Diego, CA, USA) according to the manufacturer's instructions. ELISA was performed in duplicate for each sample. The preparation of liver homogenate was done as previously described [25]. In short, frozen liver tissues were homogenized in a protein extraction solution (PRO-PREP; Intron biotechnology, Sungnam, Korea), incubated for $30 \mathrm{~min}$ on ice and then centrifuged at $13,000 \mathrm{rpm}\left(4^{\circ} \mathrm{C}\right)$ for $10 \mathrm{~min}$.

\section{Flow cytometry analysis}

The phenotype of various immune cells was evaluated by flow cytometry analysis [FACS, Epic XL, Software Expo32 (Beckman coulter)]. Briefly, splenocytes were stained with fluoresent antibodies, including anti-CD3eFITC, anti-CD8a-PerCP, anti-CD4-PE/FITC, anti-CD25PE, anti-Foxp3-PerCP, anti-CD11c-PE, anti-MHCII-FITC (eBiosciences, San Diego, CA, USA), according to the manufacturer's instructions. The percentage of each phenotype of immune cells was analyzed with the corresponding Flowjo software.

\section{Labeling of ERCs with PKH26 and in vivo tracking}

For in vivo tracking of administered ERCs, cells were isolated and labeled with PKH26 Red Fluorescent Cell Linker Kits (Sigma-aldrich, St Louis, USA), according to the manufacturer's instructions. Prepared PKH26-labeled ERCs at a final cell concentration of $1 \times 10^{7}$ cells $/ \mathrm{ml}$ were then injected via tail vein 30 min after ALI induction. Mice were executed $24 \mathrm{~h}$ later, and the liver, lung, kidney and spleen were removed and frozen at $-20{ }^{\circ} \mathrm{C}$. Fluorescence microscopy was performed to analyze the $4 \mu \mathrm{m}$ cryosections and identify the ERCs.

\section{Statistical analysis}

All the experimental data were presented as mean \pm standard error of the mean (SEM). The results were statistically analyzed by ANOVA test utilizing SPSS version 17.0 software (SPSS Inc., Chicago, USA). $p<0.05$ was considered statistically significant.

\section{Results}

\section{ERC treatment improved liver function after ALI}

The serum levels of ALT and AST in the untreated group were markedly increased after $\mathrm{CCl}_{4}$ injection compared with the normal control group ( $p<0.01$; Fig. 1a, b). In contrast, both serum levels of ALT and AST were significantly decreased by ERC treatment $(p<0.01)$, even though they were still higher than those of normal control group (Fig. 1a, b, $p<0.05$ ). In addition, we also found that serum ALT and AST rapidly elevated to peak level $24 \mathrm{~h}$ after $\mathrm{CCl}_{4}$ treatment, then decreased thereafter, while ERC treatment significantly inhibited the elevation of serum ALT and AST from 24 to $120 \mathrm{~h}$ (Data not shown). Taken together, these data suggested that ERCs improve liver function in mice with ALI.

\section{ERCs ameliorated the histopathological damage of liver tissue after acute injury}

As shown in Fig. 2, in the untreated ALI group, the liver became inflamed, turned yellowish-white, and increased in volume at $24 \mathrm{~h}$ after $\mathrm{CCl}_{4}$ injection (Fig. 2a), suggesting that $\mathrm{CCl}_{4}$ had induced severe liver cell injury. Notably, the changes observed in the ERC-treated livers were indistinguishable from those in the normal control group (Fig. 2a). In addition, degeneration of liver structure and pathological changes of hepatic parenchymal cells were observed in $\mathrm{CCl}_{4}$-induced mice, characterized by hepatocyte necrosis, shrinkage of nuclei, and infiltration of inflammatory cells in the portal area (Fig. 2b). In contrast, all these abnormal changes were alleviated at the same time point after ERC treatment (Fig. 2b). The gross findings and the pathological changes of the liver tissue in ERC-treated group were similar to those of normal controls (Fig. 2a, b). Meanwhile, in consistent with the results of liver function study, we found that the pathological changes of the liver tissue in untreated group at 48,72 , and $120 \mathrm{~h}$ time points could be reversed by ERC infusion (Data not shown). Overall, these results indicated that ERC treatment could effectively protect the liver from $\mathrm{CCl}_{4}$-induced acute liver damage. 

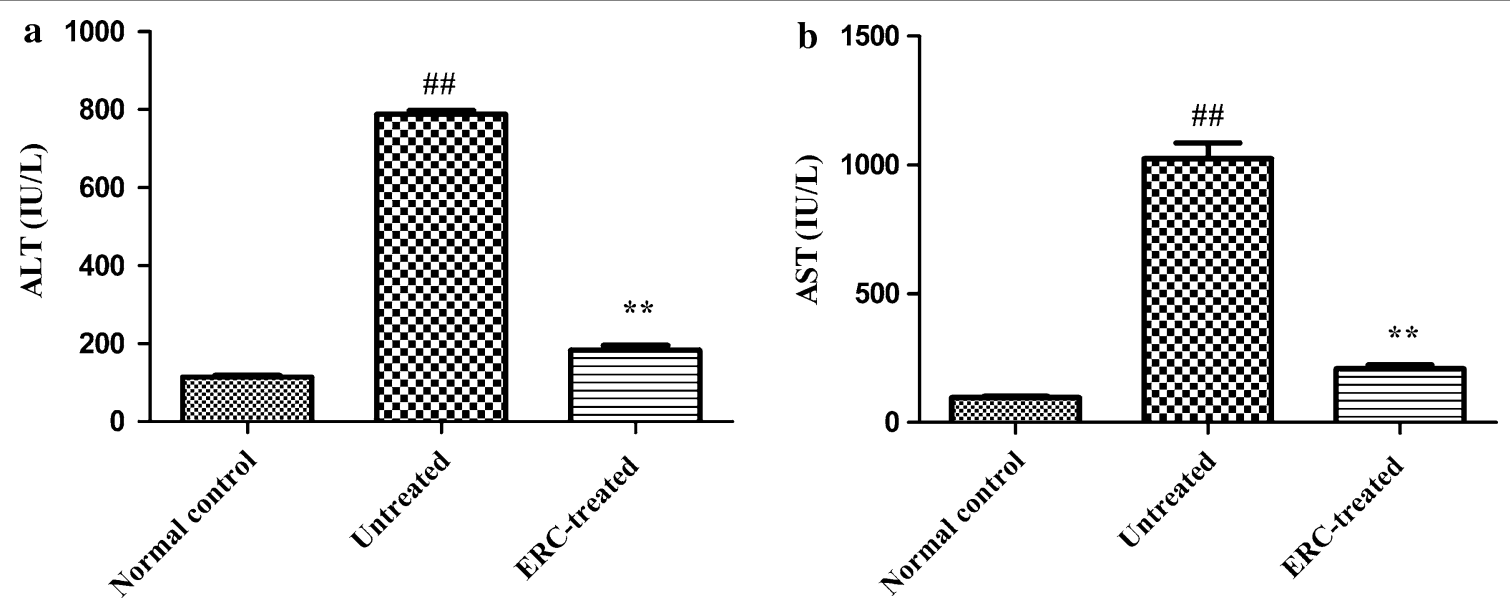

Fig. 1 ERCs improved liver function in $\mathrm{CCl}_{4}$-induced ALI mice. Serum samples were collected from mice of the normal control, untreated and ERCtreated groups. ERCs significantly reduced serum levels of $\mathbf{a}$ ALT and $\mathbf{b}$ AST in comparison with those of untreated ALI group. Bar graphs represent mean \pm SEM of three separate experiments. $p$ values were determined by one-way ANOVA. Data show are representative of three separate experiments performed. ${ }^{\# \#} p<0.01$ versus the normal control group. ${ }^{*} p<0.05,{ }^{* *} p<0.01$ versus the untreated group, $\mathrm{n}=6$ )
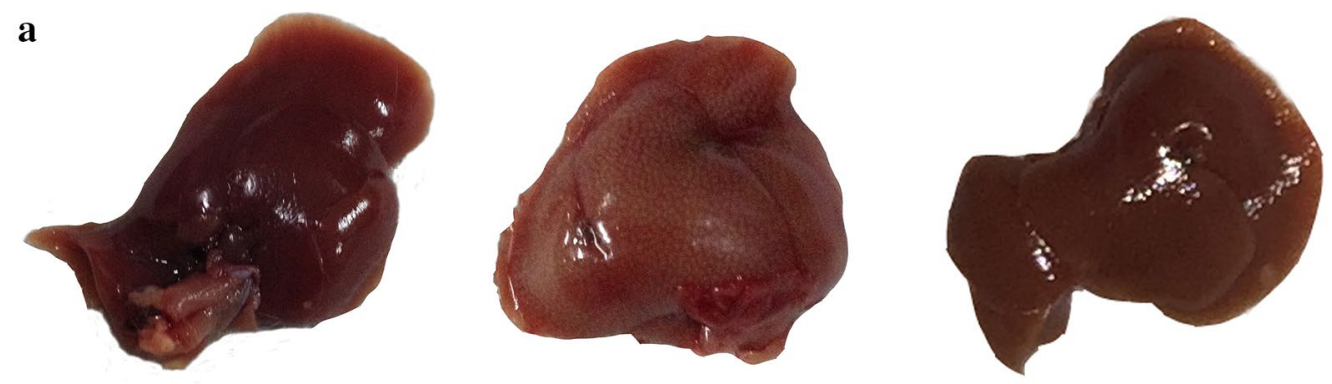

b

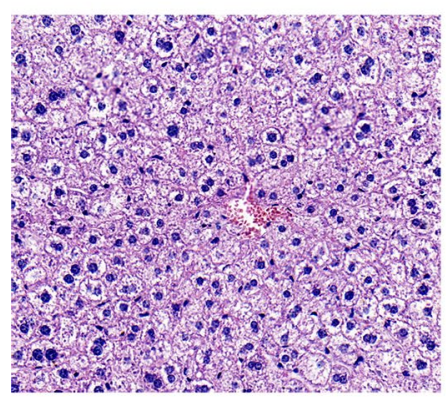

Normal control

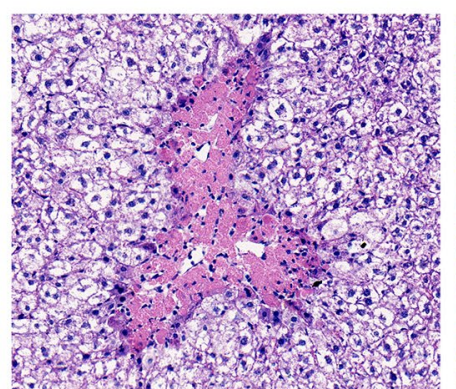

Untreated

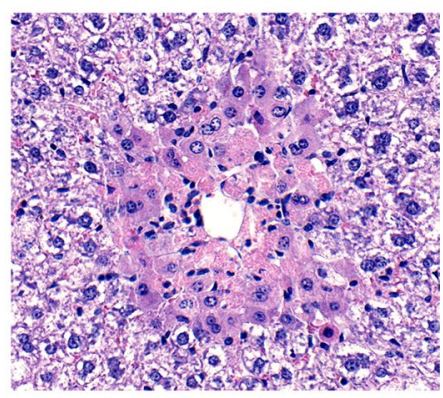

ERC-treated

Fig. 2 ERC treatment markedly attenuated histopathological damage after $\mathrm{CCl}_{4}$ induction. Mice were treated with $\mathrm{CCl}_{4}(1 \mathrm{ml} / \mathrm{kg}$ body weight and 1:3 diluted in corn oil) to induce acute liver injury, then intravenously administered with ERCs $\left(1 \times 10^{6} / 0.2 \mathrm{ml} / \mathrm{mouse}\right.$, suspended in PBS) $30 \mathrm{~min}$ after $\mathrm{CCl}_{4}$ injection, only once in $24 \mathrm{~h}$. Photographs of livers were taken $24 \mathrm{~h}$ after $\mathrm{CCl}_{4}$ injection. a indicates gross pathological changes of livers. b Representative photomicrographs of histological sections of liver (200x, haemotoxylin and eosin staining). Livers in the untreated group exhibited more ballooned hepatocytes, apoptosis and necrosis than those in the normal control groups, which were significantly alleviated by ERC treatment $(n=6)$ 


\section{ERC infusion promoted hepatocyte proliferation in mice with ALI}

To determine whether ERCs have a role in accelerating hepatocyte proliferation after ALI, PCNA expression was detected in the liver tissue by immunohistochemistry. As shown in Fig. 3, compared to the untreated group, ERC infusion dramatically increased the number of PCNA positive-staining cells at $24 \mathrm{~h}$ after $\mathrm{CCl}_{4}$ induction, with a great number of PCNA positive hepatocytes surrounding the portal area. The changes are indistinguishable from those in the normal control group. This finding demonstrated that treatment with ERCs may markedly promote liver cell proliferation after $\mathrm{CCl}_{4}$-induced ALI.

\section{ERC treatment inhibited neutrophil infiltration in the liver after ALI}

To characterize whether ERC treatment could prevent inflammatory cell infiltration following ALI, we performed immunohistochemical staining to evaluate the recruitment of neutrophils in liver tissue. As shown in Fig. 3, ERC treatment notably reduced the number of Ly6G positive cells in the liver compared to those without ERC administration. These results suggested that ERCs significantly reduced neutrophil infiltration in the liver caused by acute liver damage.

\section{ERC treatment attenuated ALI by regulating cytokine expression}

To determine whether ERC treatment could affect cytokine profiles, the levels of local and systemic inflammatory cytokines were analyzed and compared among different groups. As shown in Fig. 4, compared with the normal control group, the untreated group exhibited significantly higher levels of pro-inflammatory cytokines (IL-1 $\beta$, IL- 6 and TNF- $\alpha$ ) in both the liver $(p<0.01)$ and the serum $(p<0.01)$. In contrast, these cytokine levels were markedly reduced in ERC-treated group $(p<0.01$, versus untreated group). On the other hand, the level of anti-inflammatory cytokine IL-10 was notably elevated after ERC treatment ( $p<0.01$, versus untreated group). Taken together, these data suggested that treatment with ERCs not only suppress the level of pro-inflammatory cytokines, but also enhance the level of anti-inflammatory cytokine in $\mathrm{CCl}_{4}$-induced ALI mice.

ERC treatment decreased the percentage of $\mathrm{CD} 11 \mathrm{c}^{+} \mathrm{MHCI}^{+}$ cells in the spleen after ALI

Recently Zhang et al. and Nauta et al. demonstrated that MSCs derived from different human tissues reduced the expression of presentation molecules (MHC class II) and co-stimulatory molecules (CD80 and CD86) on mature dendritic cells (DCs) [26, 27]. In this regard, we investigated whether ERC treatment could affect the population of antigen-presenting cells in ALI mice. As shown in Fig. 5, the frequency of MHCII positive DCs in the spleen was significantly lower in ERC-treated mice compared to untreated mice $(p<0.01)$, which suggested that ERC treatment could reduce the population of mature DCs.

\section{ERCs influenced the populations of $\mathrm{CD}^{+}{ }^{+} \mathrm{CD} 4^{+}$ and $\mathrm{CD}^{+} \mathrm{CD}^{+} \mathrm{T}$ cells in ALI mice}

To study the relationship between the changes of $\mathrm{T}$ cell population and ERC-mediated liver protection, we employed flow cytometric analysis to detect the levels of $\mathrm{CD}^{+} \mathrm{CD}^{+}$and $\mathrm{CD}^{+} \mathrm{CD}^{+} \mathrm{T}$ cells in both spleen and liver. As indicated in Fig. 6, the percentages of $\mathrm{CD}^{+} \mathrm{CD}^{+}$and $\mathrm{CD}^{+}{ }^{+} \mathrm{CD} 8^{+} \mathrm{T}$ cells in the spleen were dramatically decreased as compared with those of untreated mice (Fig. 6, $p<0.01$ ). However, no difference was observed in the percentages of $\mathrm{CD} 3^{+} \mathrm{CD} 4^{+}$and $\mathrm{CD}^{+} \mathrm{CD}^{+}$in the liver in all groups (data not shown).

\section{ERC treatment upregulated splenic Treg population in ALI mice}

To further investigate the immunomodulatory function of ERCs in the attenuation of ALI, we measured and compared splenic Treg population among different groups. The percentage of Tregs in the untreated group was much lower than that of the normal control group (Fig. 7, $p<0.01$ ). In contrast, the percentage of $\mathrm{CD} 4{ }^{+} \mathrm{CD} 25^{+} \mathrm{Foxp}^{+}$Treg population was significantly increased by ERC treatment in ALI mice (Fig. 7, $p<0.01$, versus untreated group and normal control group), demonstrating that ERCs have hepato-protective effects in $\mathrm{CCl}_{4}$-induced acute liver injury through upregulation of Treg population in mice.

\section{Tracking in vivo engraftment of ERCs}

To investigate whether PHK26-ERCs are capable of engrafting $\mathrm{CCl}_{4}$-injured liver, animals were sacrificed $24 \mathrm{~h}$ after $\mathrm{CCl}_{4}$ induction. As shown in Fig. 8, PHK26positive ERCs were detected by fluorescence microscopy in the liver (injured tissue) and the spleen (lymphoid organ) of ERC-treated mice. Moreover, the labeled ERCs were aslo mainly found in the lung, but not in other normal organs, such as the kidney.

\section{Discussion}

Liver failure can be caused by acute severe or chronic persistent liver injury, while effective treatment are still scarce. Considering the current clinical state, developing an alternative therapeutic strategy to reduce damage, prevent progression, and restore liver function is warranted. Several reports have described the safety and promising beneficial effects of MSCs in the treatment of acute liver injury $[6,28]$. However, the value of ERCs, a novel 


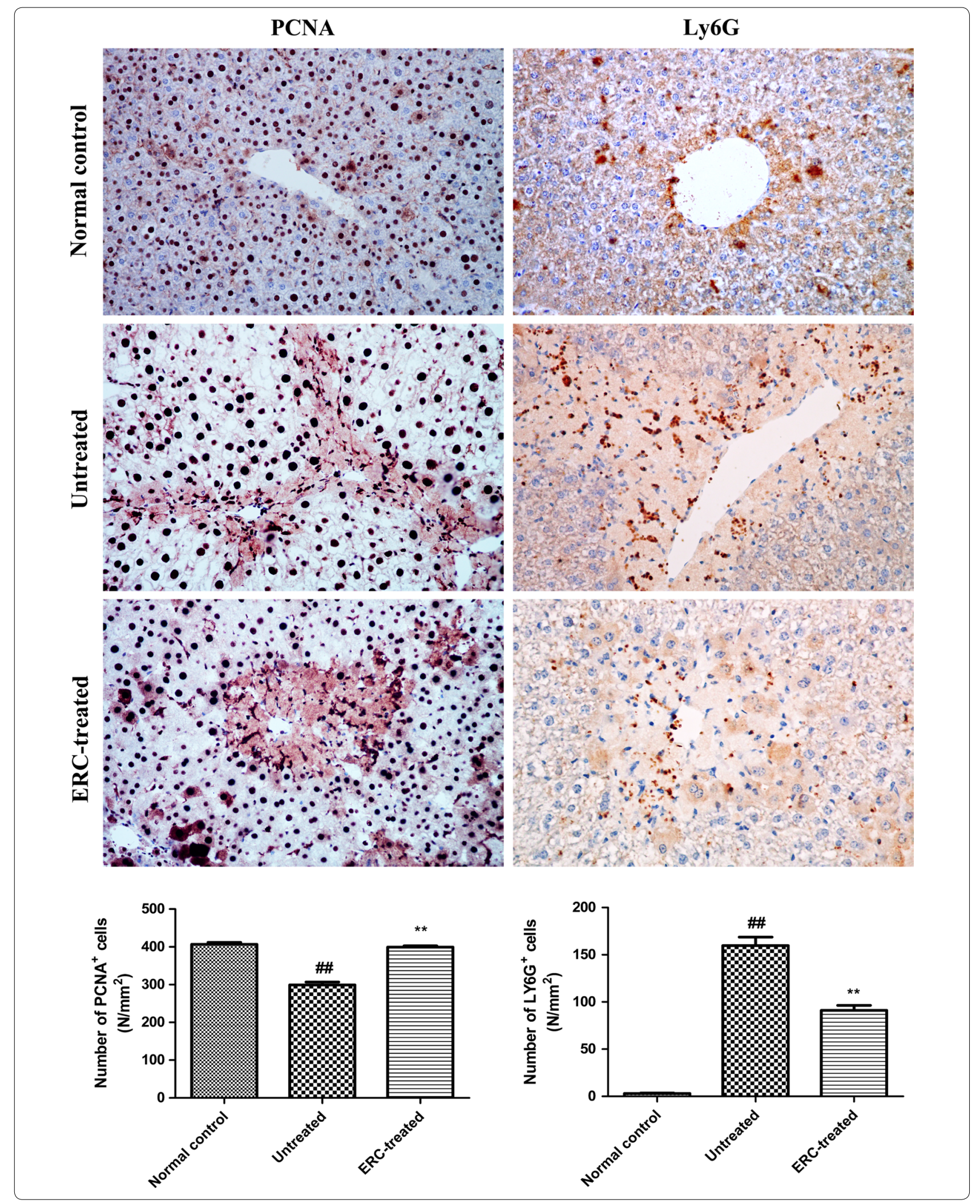


(See figure on previce page.)

Fig. 3 ERCs promoted hepatic cell proliferation and suppressed inflammatory cell infiltration after $\mathrm{CCl}_{4}$ injury. Immunohistochemical staining for PCNA and Ly6G were carried out as previous described. PCNA and Ly6G staining of liver sections in the mice with or without ERC administration were performed $24 \mathrm{~h}$ after $\mathrm{CCl}_{4}$ treatment. The untreated group showed relatively few PCNA ${ }^{+}$hepatocytes and abundant Ly6G ${ }^{+}$cells in centrilobular areas. Sections from ERCs treated group exhibited numerous PCNA ${ }^{+}$hepatocytes surrounding the edge of hepatocellular necrosis and fewer inflammatory cell accumulating in liver tissues. The numbers of $\mathrm{PCNA}^{+}$and $\mathrm{Ly}_{6 \mathrm{G}}{ }^{+}$cells in the liver sections were measured. At least six $12 \mathrm{~mm}{ }^{2}$ tissue sections were counted for each mouse. Values represent mean \pm SEM. $\left({ }^{\# \#} p<0.01\right.$ versus the normal control group. ${ }^{*} p<0.05,{ }^{* *} p<0.01$ versus the untreated group, $n=6$ ). (Magnification 100x)

type of MSCs obtained from menstrual blood, in ALI has not been studied. Compared with MSCs from other sources, ERCs have several additional outstanding merits, such as (1) abundant availability, (2) easy and noninvasive acquisition and separation method, (3) higher proliferative rate, (4) relatively unlimited expandability without karyotypic or functional abnormality, (5) more multi-lineage differentiation capacities [29]. In this study, we observed that ERC therapy is an effective strategy for alleviation of ALI. We mainly focused on investigating the therapeutic potential of ERCs related to anti-inflammation, immunomodulation, promotion of hepatocyte
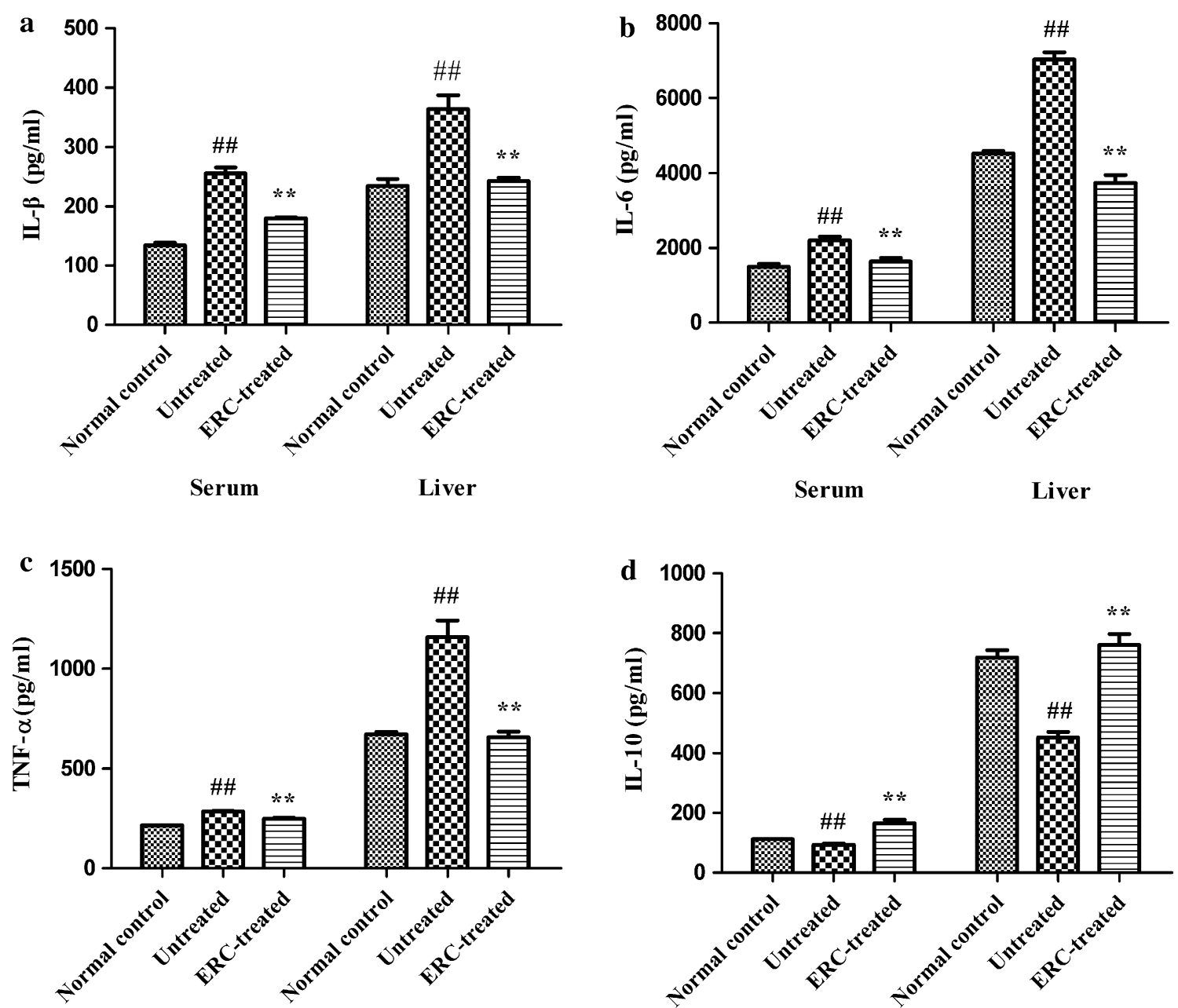

Serum

Liver

Serum

Liver

Fig. 4 Treatment with ERCs diminished ALI by regulating cytokine profiles. The levels of IL-1 $\beta$, IL-6, TNF-a, and IL-10 in sera and liver tissues were detected by ELISA at indicated time points after $\mathrm{CCl}_{4}$ challenge. Data indicated that ERC treatment significantly decreased the levels of $\mathbf{a} I L-1 \beta, \mathbf{b}$ $\mathrm{IL}-6$, and $\mathbf{c}$ TNF-a, while increased the level of $\mathbf{d} \mathrm{IL}-10$ in $\mathrm{CCl}_{4}$-induced ALI. Values represent mean \pm SEM. $\#^{\#} p<0.01$ versus the normal control group. ${ }^{*} p<0.05,{ }^{* *} p<0.01$ versus the untreated group, $\mathrm{n}=6$ ) 


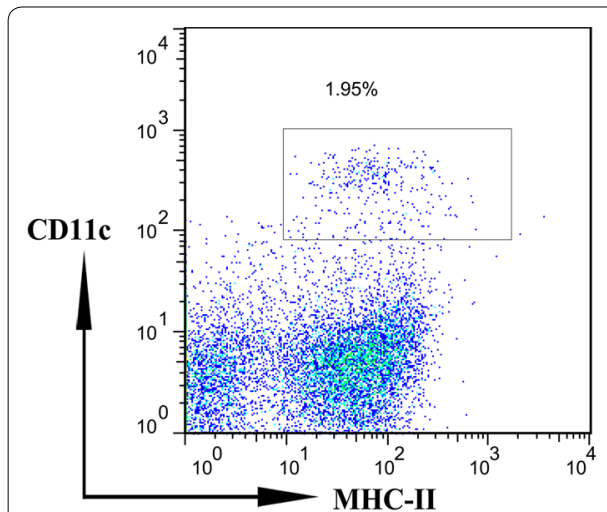

Normal control

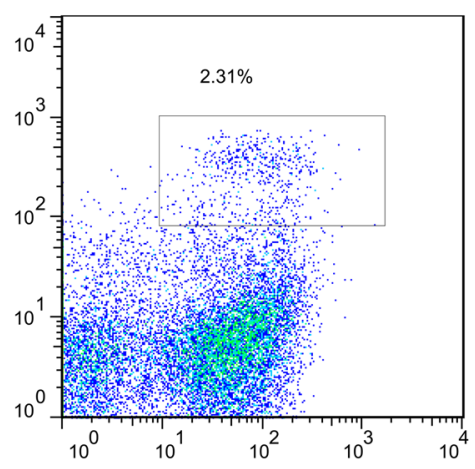

Untreated

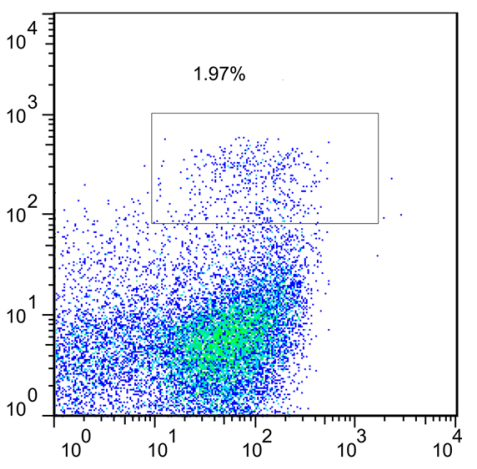

ERC-treated

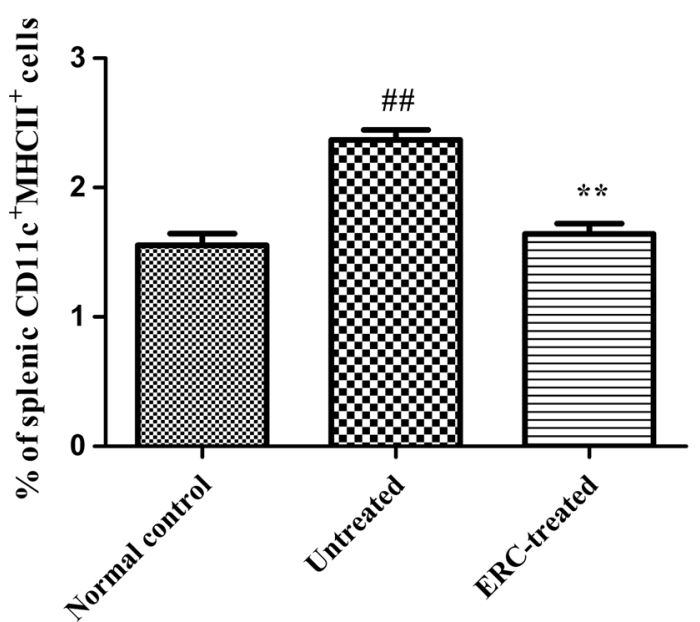

Fig. 5 ERCs alleviated ALI by modulating the frequency of DCs. Flow cytometric analysis of splenic DC population was performed in the normal control, untreated and ERC-treated groups. ERC treatment dramaticlly lowered the frequency of CD11 $\mathrm{c}^{+} \mathrm{MHCI}{ }^{+}$cells in ALI mice compared with those of untreated ALI mice. Bar graphs represent mean \pm SEM of three separate experiments. $p$ values were determined by one-way ANOVA. Data show are representative of three separate experiments performed. $\left({ }^{\# \#} p<0.01\right.$ versus the normal control group. ${ }^{*} p<0.05,{ }^{* *} p<0.01$ versus the untreated group, $\mathrm{n}=6$ )

proliferation, as well as their engraftment after ERC infusion.

In the present study, we took the advantage of the mouse ALI model to mimic clinical liver dysfunction for evaluating the efficacy of ERC treatment. The mice exposed to $\mathrm{CCl}_{4}$ showed significant increase of ALT and AST, which were reduced by ERCs from an early phase of liver injury. Furthermore, livers of the untreated group became inflamed, turned yellowish-white, and increased in volume at $24 \mathrm{~h}$ after $\mathrm{CCl}_{4}$ injection, suggesting that $\mathrm{CCl}_{4}$ had induced severe liver cell injury. Notably, the changes of gross findings observed in ERC-treated livers were indistinguishable from those in the normal control group. In accordance with this finding, the histopathological results demonstrated that ERC administration prominently alleviated cytoplasmic vacuolization, necrosis and infiltration of inflammatory cells. Furthermore, to clarify if the similar beneficial effects of ERC injection be seen longer term, the effects of ERC infusion at different time points have also been studied. The results of biochemical assays and histological examination showed that similar beneficial effects could still be observed 2, 3 and 5 days after ALI induction. Meanwhile, ERCs could still provide a similar benefit when infused $2 \mathrm{~h}$ after ALI as $30 \mathrm{~min}$ after induction. Taken together, ERCs exhibited liver protective effects on this model of liver damage.

Accumulating evidences indicate that hepatocyte proliferation in stem cell therapy is closely related to increased expression of endogenous and exogenous trophic molecules, including growth factors, transforming growth factor, vascular endothelial growth factor and so on [30]. Similar mechanisms have been reported in 


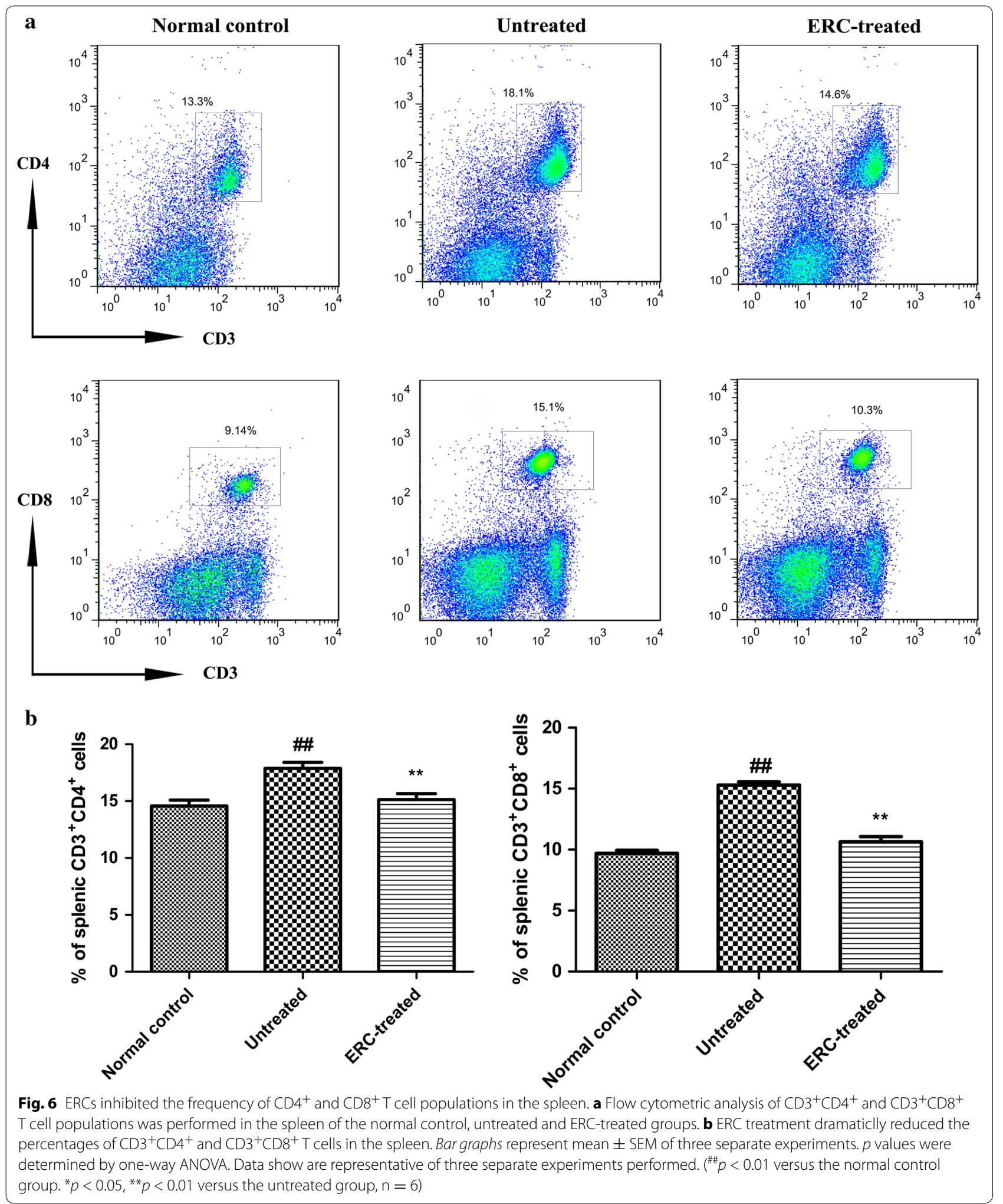




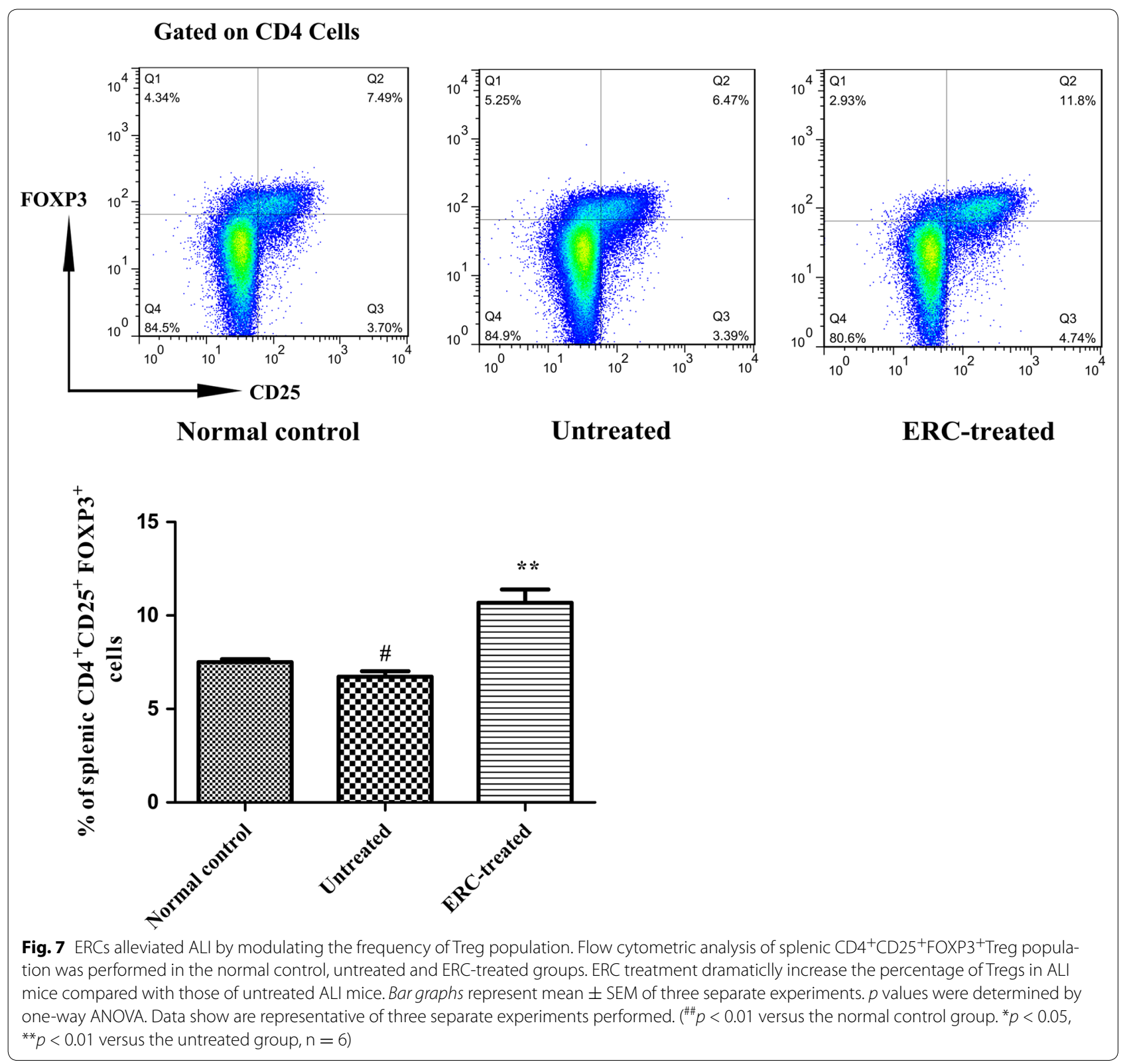

acute kidney failure and stroke models [31, 32]. In addition, some in vitro studies also proved that ERCs could differentiate into functional hepatocyte-like cells [13, 33]. To determine the effect of ERCs on liver cell proliferation, we performed PCNA immunohistochemistry. It was found that the population of PCNA positive cells was significantly higher in the ERC-treated group than that of the untreated group, demonstrating that ERCs could promote hepatocyte proliferation.

Neutrophils, a type of phagocytic cell, are potent immune regulators which play an important role in the inflammatory response [34]. Neutrophils have been implicated in several liver injury models such as alcoholic hepatitis [35], ischemia/reperfusion injury of the liver [36], and concanavalin A-induced liver injury [37]. In vivo studies have also exhibited that pathological changes in ALI are significantly improved in neutrophil-depleted mice [36, 38]. Our study demonstrated that ERCs could significantly reduce the numbers of Ly6G-positive cells in the liver compared to that of the untreated group. Therefore, we speculated that ERC treatment contributed to alleviating hepatocellular damage against $\mathrm{CCl}_{4}$-induced ALI by suppressing inflammatory cell infiltration. 

Local down-regulation of pro-inflammatory cytokines and up-regulation of anti-inflammatory cytokines after MSC transplantation have been described in kidney, lung and liver injury models [31, 39, 40]. To address whether ERCs share the similar attributes in amelioration of liver damage partially through regulating cytokine profiles in the ALI model, we measured the local and serum levels of cytokines. Our data showed that treatment with ERCs dramatically reduced the levels of pro-inflammatory cytokines (IL-6, IL-1 $\beta$, TNF- $\alpha$ ) and increased IL-10, and anti-inflammatory cytokine, compared to those of untreated mice. It has been known that the three acute-phase proteins, IL- $1 \beta$, IL- 6 , and TNF- $\alpha$, are tightly associated with inflammation and cell proliferation and viewed as biomarkers that reflect inflammatory conditions [41]. IL-1 $\beta$ has been previously shown to hamper hepatocyte proliferation [42, 43]. Both IL-1 $\beta$ and IL-1R-deficient mice were not sensitive to inflammatory conditions at the acute phase [44]. IL- 6 and TNF- $\alpha$ have also been identified as attractive targets for initiation and progression of liver regeneration. Increasing evidence has shown that IL-6 hyperstimulation is more likely to cause liver injury $[45,46]$. In another study, it was found that ischemia-induced renal damage was ameliorated in IL-6 knockout mice [47]. TNF- $\alpha$, produced by Kupffer cells (macrophages in liver), acts as a pro-inflammatory mediator in liver apoptosis closely related with cytotoxicity induced by $\mathrm{CCl}_{4}[48,49]$. Okajima et al. discovered that pretreatment with anti-rat TNF- $\alpha$ antibody could significantly inhibit hepatic I/R [50]. In the current study, the levels of all these three cytokines were reduced by ERC treatment, indicating that ERCs may directly inhibit the pro-inflammatory cytokine secretion to exert liver protective effects.

Meanwhile, previous studies reported that MSCs could secrete IL-10 directly and promote the production of IL-10 by other antigen-presenting cells to exert anti-inflammatory and immunomodulatory effects [51, 52]. It was claimed that IL-10 has a protective function in the liver injury animal model [53]. IL-10 negatively regulates liver regeneration by suppressing production of pro-inflammatory cytokines and inhibiting macrophage and neutrophil recruitment in hepatocytes [54]. The liver protective effect was abolished in IL-10-deficient mice and administration of recombinant IL-10 rescued these mice from chemical-induced hepatitis $[25,51]$. In the present study, the levels of IL-10 in the liver and serum were elevated by ERC treatment, suggesting that ERCs may protect the mice from ALI by up-regulating IL-10 both locally and systematically.

Previous studies demonstrated MSCs preferentially integrated into injured liver and enhanced hepatocyte regeneration when infused into $\mathrm{CCl}_{4}$ injured mice $[28,55$, 56]. Similarly, we transplanted xenogeneic PHK26-ERCs via intravenous injection and found that the transplanted human ERCs quickly migrated into the liver lobules in mice and could be visualized as scattered individual cells $24 \mathrm{~h}$ after $\mathrm{CCl}_{4}$ administration. Additionally, the level of PCNA positive cells was significantly enhanced after ERC infusion, implying that human ERCs can migrate into the liver and promote liver regeneration in this ALI model. This notion is supported by previous studies that therapeutic effects of ERCs were observed despite utilization of human cells in an immuno-competent xenogeneic animal [13]. Thus, we speculated that ERCs may contribute to hepatocyte proliferation within this damaged environment. In the current study we have also confirmed that ERCs mainly accumulate in the lungs within $24 \mathrm{~h}$ after intravenous infusion. This is in accordance with earlier findings that the exogenous fluorescently labelled MSCs remained viable in the lungs up to $24 \mathrm{~h}$ after injection [57]. Notably, more fluorescently marked cells were also found in the spleen. Accordingly, the populations of immune cells in spleen were studied to explore the relationship between ERCs and systemic immune reaction.

Dendritic cells (DCs) are the principal antigen-presenting cells in lymphoid organs and periphery including the liver, and are key mediators for the initiation and regulation of both innate and adaptive immune responses $[58,59]$. It has been reported that DCs exhibit fibrolytic properties, and the depletion of $\mathrm{CD} 11 \mathrm{c}^{+}$cells in the $\mathrm{CCl}_{4}$-induced liver fibrosis model led to slower fibrosis regression and reduced clearance of activated hepatic stellate cells. Conversely, DC expansion induced either by Flt3L (fms-like tyrosine kinase-3 ligand) or adoptive transfer of purified DCs accelerates liver fibrosis regression [60]. In the current study, we evaluated the number of splenic DCs distant from the liver, and observed that the elevation of $\mathrm{CD} 11 \mathrm{c}^{+} \mathrm{MHC}-\mathrm{II}^{+} \mathrm{DC}$ population after $\mathrm{CCl}_{4}$ challenge was significantly reduced by ERC treatment. This is consistent with the finding that MSCs are capable of inhibiting the differentiation of monocytes into DCs [26, 27], suggesting that ERCs probably exert immunomodulatory effects on DCs to control the development of ALI.

$\mathrm{T}$ lymphocyte subsets, including $\mathrm{CD} 4^{+}$and $\mathrm{CD} 8^{+} \mathrm{T}$ cells, play an important role in the pathogenesis of liver disease [61, 62]. However, the effect of $\mathrm{CD} 4^{+}$and $\mathrm{CD} 8^{+}$ $\mathrm{T}$ cells on $\mathrm{CCl}_{4}$-induced acute hepatotoxicity in mice remains scarce and even controversial. According to previous studies, antigen-specific $\mathrm{CD} 8^{+} \mathrm{T}$ cells migrate to the contact site upon re-exposure to the chemicals and cause tissue damage through the release of cytokines and cytolytic molecules [63-66]. Researchers used an anti-CD8 monoclonal antibody to neutralized CD8 T 
cells and demonstrated that depletion of CD8 T cells protected mice from Amodiaquine-induced liver injury [67]. Results from other experiments confirmed that $\mathrm{CD}^{+} \mathrm{T}$ cell depletion was capable of ameliorating the extent of injury with less neutrophil infiltration after $I / R$ liver damage; however, liver damage was reproduced when adoptive transfer of $\mathrm{CD}_{4}^{+}$lymphocytes to $\mathrm{CD} 4$ knockout mice [68, 69]. In our study, as compared with the untreated ALI group, ERC treatment group experienced a significant reduction in $\mathrm{CD} 4^{+}$and $\mathrm{CD} 8^{+} \mathrm{T}$ cells, indicating that ERCs may inhibit $\mathrm{T}$ cell accumulation. The findings suggested that ERCs may have regulatory functions on the cell populations of splenic $\mathrm{CD}^{+}$and $\mathrm{CD}^{+} \mathrm{T}$ cells. Similar results were also found in animal models with renal I/R injury and ulcerative colitis [15, 20]. Meanwhile, this study also proved that, like MSCs, ERCs possess immunomodulatory properties which could suppress the activation and proliferation of $\mathrm{T}$ cells [70].

Tregs are believed to play a critical role in the suppression of both innate and adaptive immune responses [71], and are also an important factor in the attenuation of liver injury [72-74]. $\mathrm{CD} 4^{+} \mathrm{CD} 25^{+}$Tregs account for $5-10 \%$ of the $\mathrm{CD} 4^{+} \mathrm{T}$ cell panel in healthy humans and mice, which is sufficient to maintain immune homeostasis and limit autoimmune disease [75]. The role of Tregs in ALI has been confirmed in several studies using PC61, an anti-CD25 monoclonal antibody that depletes Tregs before liver damage, to verify the protective effect of Tregs. It was found that mice suffering from Treg depletion experienced an aggravation of ALI compared to ALI mice that did not have Treg depletion [25]. In another study, the protective effects of Tregs on ALI were confirmed via the adoptive transfer method [76]. Similarly, our results demonstrated that $\mathrm{CD} 44^{+} \mathrm{CD} 25^{+} \mathrm{Foxp} 3^{+}$ Tregs were significantly decreased in the untreated-ALI mice compared to the normal control mice, and significantly elevated in ERC-treated mice, indicating that ERC treatment mitigated $\mathrm{CCl}_{4}$-induced acute hepatotoxicity in mice by increasing the population of Tregs. Overall, we speculate that transplanted PKH26-labeled ERCs engraft to the spleen in mice with ALI and interact with immune cells, leading to the downregulation of

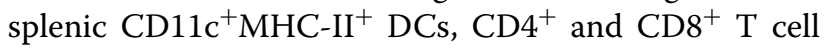
population, as well as the upregulattion of Treg population. In the meantime, since ERC supernatant could still exert similar beneficial effects on ALI as compared to the effects achieved by cell infusion (Data not shown), ERC treatment may also attenuate ALI by releasing immunomodulatory cytokines. Experiments to better understand the mechanisms of ERC-mediated immunomodulation in this ALI model are underway.

\section{Conclusions}

In conclusion, our study demonstrated that human ERCs are effective in treating $\mathrm{CCl}_{4}$-induced ALI. ERCs improved liver function and attenuated pathological changes by promoting liver cell regeneration, modulating cytokine profiles, and regulating immune cells. However, further studies are still needed to elucidate the complex pathways underlying ERC-mediated liver protective effects at molecular levels. Taken together, these findings may provide a rationale for the use of ERCs in clinical settings.

\section{Abbreviations \\ ALI: acute liver injury; ALT: alanine aminotransferase; AST: aspartate ami- notransferase; $\mathrm{CCl}_{4}$ : carbon tetrachloride; DCs: dendritic cells; ERC: endometrial regenerative cells; IL: interleukin; Ly6G: lymphocyte antigen 6 complex, locus G; MSCs: mesenchymal stem cells; PCNA: proliferating cell nuclear antigen; Treg: regulatory $T$ cell; TNF: tumor necrosis factor.}

\section{Authors' contributions}

SL, GS and XX carried out the research, analyzed the data and drafted the manuscript; GW participated in research design and manuscript editing; XL, PS, XL and BZ performed the research and analyzed the data; $X G$ and TI participated in the design of the study. HW conceived of the study, participated in research design and coordination, and helped to draft and edit the manuscript. All authors read and approved the final manuscript.

\section{Author details \\ ${ }^{1}$ Department of General Surgery, Tianjin Medical University General Hospital, 154 Anshan Road, Heping District, Tianjin 300052, China. ${ }^{2}$ Tianjin General Surgery Institute, Tianjin, China. ${ }^{3}$ Faculty of Medicine, University of Toronto, Toronto, ON, Canada. ${ }^{4}$ Department of General Surgery, Affiliated Hospital of Weifang Medical University, Shandong, China. ${ }^{5}$ Department of Gynecol- ogy and Obstetrics, Tianjin Medical University General Hospital, Tianjin, China. ${ }^{6}$ Immune Advisors LLC, San Diego, CA 92121, USA.}

\section{Acknowledgements}

We gratefully acknowledge Dr. Hongyue Li for his technical support and review of pathological and immunohistochemical slides to ensure quality control and accuracy.

\section{Competing interests}

The authors declare that they have no competing interests.

\section{Availability of data and materials}

The dataset supporting the conclusions of this article is included within the article.

\section{Ethics approval and consent to participate}

This study was following the Animal Care and Use Committee of Tianjin Medical University (Tianjin, China) according to the Chinese Council on Animal Care guidelines. The reference number is IRB2016-YX-022.

\section{Funding}

This work was supported by grants to H.W. from National Natural Science Foundation of China (No. 81273257 and 81471584), Tianjin Application Basis and Cutting-Edge Technology Research Grant (No. 14JCZDJC35700), Li Jieshou Intestinal Barrier Research Special Fund (No. LS_201412), and Tianjin Medical University Talent Fund.

Received: 31 July 2016 Accepted: 5 October 2016

Published online: 22 October 2016 


\section{References}

1. Bernal W, Auzinger G, Dhawan A, Wendon J. Acute liver failure. Lancet. 2010;376:190-201.

2. Stravitz RT, Kramer DJ. Management of acute liver failure. Nat Rev Gastroenterol Hepatol. 2009:6:542-53.

3. Yamaza T, Alatas FS, Yuniartha R, Yamaza H, Fujiyoshi JK, Yanagi Y, Yoshimaru K, Hayashida M, Matsuura T, Aijima R, et al. In vivo hepatogenic capacity and therapeutic potential of stem cells from human exfoliated deciduous teeth in liver fibrosis in mice. Stem Cell Res Ther. 2015:6:171.

4. Ren G, Chen X, Dong F, Li W, Ren X, Zhang Y, Shi Y. Concise review: mesenchymal stem cells and translational medicine: emerging issues. Stem Cells Transl Med. 2012;1:51-8.

5. Burra P, Tomat S, Villa E, Gasbarrini A, Costa AN, Conconi MT, Forbes SJ, Farinati F, Cozzi E, Alison MR, Russo FP. Experimental hepatology applied to stem cells. Dig Liver Dis. 2008;40:54-61.

6. Zhao L, Feng Z, Hu B, Chi X, Jiao S. Ex vivo-expanded bone marrow mesenchymal stem cells facilitate recovery from chemically induced acute liver damage. Hepatogastroenterology. 2012;59:2389-94.

7. De Miguel MP, Fuentes-Julian S, Blazquez-Martinez A, Pascual CY, Aller MA, Arias J, Arnalich-Montiel F. Immunosuppressive properties of mesenchymal stem cells: advances and applications. Curr Mol Med. 2012:12:574-91.

8. Caplan Al. Adult mesenchymal stem cells and the NO pathways. Proc Natl Acad Sci USA. 2013;110:2695-6.

9. Xu YQ, Liu ZC. Therapeutic potential of adult bone marrow stem cells in liver disease and delivery approaches. Stem Cell Rev. 2008:4:101-12.

10. Cai YF, Zhen ZJ, Min J, Fang TL, Chu ZH, Chen JS. Selection, proliferation and differentiation of bone marrow-derived liver stem cells with a culture system containing cholestatic serum in vitro. World J Gastroenterol. 2004;10:3308-12

11. Rao MS, Mattson MP. Stem cells and aging: expanding the possibilities. Mech Ageing Dev. 2001;122:713-34

12. Meng $X$, Ichim TE, Zhong J, Rogers A, Yin Z, Jackson J, Wang H, Ge W, Bogin V, Chan KW, et al. Endometrial regenerative cells: a novel stem cell population. J Transl Med. 2007:5:57.

13. Murphy MP, Wang H, Patel AN, Kambhampati S, Angle N, Chan K, Marleau AM, Pyszniak A, Carrier E, Ichim TE, Riordan NH. Allogeneic endometrial regenerative cells: an "Off the shelf solution" for critical limb ischemia? J Transl Med. 2008;6:45.

14. Lv Y, Xu X, Zhang B, Zhou G, Li H, Du C, Han H, Wang H. Endometrial regenerative cells as a novel cell therapy attenuate experimental colitis in mice. J Transl Med. 2014;12:344.

15. Drago H, Marin GH, Sturla F, Roque G, Martire K, Diaz Aquino V, Lamonega R, Gardiner C, Ichim T, Riordan N, et al. The next generation of burns treatment: intelligent films and matrix, controlled enzymatic debridement, and adult stem cells. Transplant Proc. 2010;42:345-9.

16. Sun P, Liu J, Li W, Xu X, Gu X, Li H, Han H, Du C, Wang H. Human endometrial regenerative cells attenuate renal ischemia reperfusion injury in mice. J Transl Med. 2016;14:28

17. Wolff EF, Mutlu L, Massasa EE, Elsworth JD, Eugene Redmond D, Taylor HS Jr. Endometrial stem cell transplantation in MPTP- exposed primates: an alternative cell source for treatment of Parkinson's disease. J Cell Mol Med. 2015:19:249-56.

18. Santamaria X, Massasa EE, Feng Y, Wolff E, Taylor HS. Derivation of insulin producing cells from human endometrial stromal stem cells and use in the treatment of murine diabetes. Mol Ther. 2011;19:2065-71.

19. Borlongan CV, Kaneko Y, Maki M, Yu SJ, Ali M, Allickson JG, Sanberg CD, Kuzmin-Nichols N, Sanberg PR. Menstrual blood cells display stem celllike phenotypic markers and exert neuroprotection following transplantation in experimental stroke. Stem Cells Dev. 2010;19:439-52.

20. Khademi F, Soleimani M, Verdi J, Tavangar SM, Sadroddiny E, Massumi $\mathrm{M}$, Ai J. Human endometrial stem cells differentiation into functional hepatocyte-like cells. Cell Biol Int. 2014;38:825-34.

21. Zhang JQ, Shi L, Xu XN, Huang SC, Lu B, Ji LL, Wang ZT. Therapeutic detoxification of quercetin against carbon tetrachloride-induced acute liver injury in mice and its mechanism. J Zhejiang Univ Sci B. 2014;15:1039-47.

22. Zhang F, Wang X, Qiu X, Wang J, Fang H, Wang Z, Sun Y, Xia Z. The protective effect of Esculentoside A on experimental acute liver injury in mice. PLOS ONE. 2014;9:e113107.
23. Pascual-Miguelanez I, Salinas-Gomez J, Fernandez-Luengas D, VillarZarra K, Clemente LV, Garcia-Arranz M, Olmo DG. Systemic treatment of acute liver failure with adipose derived stem cells. J Invest Surg. 2015;28:120-6.

24. Hagiwara S, Iwasaka H, Hasegawa A, Koga H, Noguchi T. Effects of hyperglycemia and insulin therapy on high mobility group box 1 in endotoxininduced acute lung injury in a rat model. Crit Care Med. 2008:36:2407-13.

25. Kim H, Keum DJ, Kwak J, Chung HS, Bae H. Bee venom phospholipase A2 protects against acetaminophen-induced acute liver injury by modulating regulatory T cells and IL-10 in mice. PLoS ONE. 2014;9:e114726.

26. Jiang $X X$, Zhang $Y$, Liu B, Zhang SX, Wu Y, Yu XD, Mao N. Human mesenchymal stem cells inhibit differentiation and function of monocytederived dendritic cells. Blood. 2005;105:4120-6.

27. Nauta AJ, Kruisselbrink AB, Lurvink E, Willemze R, Fibbe WE. Mesenchymal stem cells inhibit generation and function of both CD34+-derived and monocyte-derived dendritic cells. J Immunol. 2006;177:2080-7.

28. Deng L, Liu G, Wu X, Wang Y, Tong M, Liu B, Wang K, Peng Y, Kong X. Adipose derived mesenchymal stem cells efficiently rescue carbon tetrachloride-induced acute liver failure in mouse. Sci World J. 2014:2014:103643.

29. Zhong Z, Patel AN, Ichim TE, Riordan NH, Wang H, Min WP, Woods EJ, Reid M, Mansilla E, Marin GH, et al. Feasibility investigation of allogeneic endometrial regenerative cells. J Transl Med. 2009;7:15.

30. Tsolaki E, Yannaki E. Stem cell-based regenerative opportunities for the liver: state of the art and beyond. World J Gastroenterol. 2015;21:12334-50.

31. Togel F, Hu Z, Weiss K, Isaac J, Lange C, Westenfelder C. Administered mesenchymal stem cells protect against ischemic acute renal failure through differentiation-independent mechanisms. Am J Physiol Rena Physiol. 2005;289:F31-42.

32. Seyfried D, Ding J, Han Y, Li Y, Chen J, Chopp M. Effects of intravenous administration of human bone marrow stromal cells after intracerebral hemorrhage in rats. J Neurosurg. 2006:104:313-8.

33. Mou XZ, Lin J, Chen JY, Li YF, Wu XX, Xiang BY, Li CY, Ma JM, Xiang C. Menstrual blood-derived mesenchymal stem cells differentiate into functional hepatocyte-like cells. J Zhejiang Univ Sci B. 2013;14:961-72.

34. Wang Q, Ding G, Xu X. Immunomodulatory functions of mesenchymal stem cells and possible mechanisms. Histol Histopathol. 2016;31(9):11750.

35. Bautista AP. Chronic alcohol intoxication induces hepatic injury through enhanced macrophage inflammatory protein-2 production and intercellular adhesion molecule-1 expression in the liver. Hepatology. 1997;25:335-42.

36. Jaeschke H, Farhood A, Smith CW. Neutrophils contribute to ischemia/ reperfusion injury in rat liver in vivo. FASEB J. 1990;4:3355-9.

37. Bonder CS, Ajuebor MN, Zbytnuik LD, Kubes P, Swain MG. Essential role for neutrophil recruitment to the liver in concanavalin A-induced hepatitis. J Immunol. 2004;172:45-53.

38. Jaeschke H, Liu J. Neutrophil depletion protects against murine acetaminophen hepatotoxicity: another perspective. Hepatology. 2007;45:1588-9 (author reply 1589)

39. Ortiz LA, Dutreil M, Fattman C, Pandey AC, Torres G, Go K, Phinney DG. Interleukin 1 receptor antagonist mediates the antiinflammatory and antifibrotic effect of mesenchymal stem cells during lung injury. Proc Nat Acad Sci USA. 2007:104:11002-7.

40. Li Q, Zhou X, Shi Y, Li J, Zheng L, Cui L, Zhang J, Wang L, Han Z, Han Y, Fan D. In vivo tracking and comparison of the therapeutic effects of MSCs and HSCs for liver injury. PLOS ONE. 2013;8:e62363.

41. Reyes-Gordillo K, Segovia J, Shibayama M, Vergara P, Moreno MG, Murie P. Curcumin protects against acute liver damage in the rat by inhibiting NF-kappaB, proinflammatory cytokines production and oxidative stress. Biochim Biophys Acta. 2007:1770:989-96.

42. Wang Z, Wang M, Carr BI. The inhibitory effect of interleukin 1 beta on rat hepatocyte DNA synthesis is mediated by nitric oxide. Hepatology. 1998;28:430-5

43. Ogiso T, Nagaki M, Takai S, Tsukada Y, Mukai T, Kimura K, Moriwaki H. Granulocyte colony-stimulating factor impairs liver regeneration in mice through the up-regulation of interleukin-1 beta. J Hepatol. 2007:47:816-25. 
44. Shornick LP, De Togni P, Mariathasan S, Goellner J, Strauss-Schoenberger J, Karr RW, Ferguson TA, Chaplin DD. Mice deficient in IL-1 beta manifest impaired contact hypersensitivity to trinitrochlorobenzone. J Exp Med. 1996;183:1427-36.

45. Wustefeld T, Rakemann T, Kubicka S, Manns MP, Trautwein C. Hyperstimulation with interleukin 6 inhibits cell cycle progression after hepatectomy in mice. Hepatology. 2000;32:514-22.

46. Campbell JS, Prichard L, Schaper F, Schmitz J, Stephenson-Famy A, Rosenfeld ME, Argast GM, Heinrich PC, Fausto N. Expression of suppressors of cytokine signaling during liver regeneration. J Clin Invest. 2001:107:1285-92.

47. Kielar ML, John R, Bennett M, Richardson JA, Shelton JM, Chen L, Jeyarajah DR, Zhou XJ, Zhou H, Chiquett B, et al. Maladaptive role of IL-6 in ischemic acute renal failure. J Am Soc Nephrol. 2005;16:3315-25.

48. Wu YL, Lian LH, Wan Y, Nan JX. Baicalein inhibits nuclear factor-kappaB and apoptosis via c-FLIP and MAPK in D-GalN/LPS induced acute liver failure in murine models. Chem Biol Interact. 2010;188:526-34.

49. Diao Y, Zhao XF, Lin JS, Wang QZ, Xu RA. Protection of the liver against CCl4-induced injury by intramuscular electrotransfer of a kallistatinencoding plasmid. World J Gastroenterol. 2011;17:111-7.

50. Okajima K, Harada N, Kushimoto S, Uchiba M. Role of microthrombus formation in the development of ischemia/reperfusion-induced liver injury in rats. Thromb Haemost. 2002;88:473-80.

51. Shi Y, Su J, Roberts Al, Shou P, Rabson AB, Ren G. How mesenchymal stem cells interact with tissue immune responses. Trends Immunol. 2012;33:136-43.

52. Dorronsoro A, Fernandez-Rueda J, Fechter K, Ferrin I, Salcedo JM, Jakobsson E, Trigueros C. Human mesenchymal stromal cell-mediated immunoregulation: mechanisms of action and clinical applications. Bone Marrow Res. 2013;2013:203643.

53. Louis H, Le Moine O, Peny MO, Gulbis B, Nisol F, Goldman M, Deviere J. Hepatoprotective role of interleukin 10 in galactosamine/lipopolysaccharide mouse liver injury. Gastroenterology. 1997;112:935-42.

54. Yin S, Wang H, Park O, Wei W, Shen J, Gao B. Enhanced liver regeneration in IL-10-deficient mice after partial hepatectomy via stimulating inflammatory response and activating hepatocyte STAT3. Am J Pathol. 2011:178:1614-21.

55. Grisafi D, Piccoli M, Pozzobon M, Ditadi A, Zaramella P, Chiandetti L, Zanon GF, Atala A, Zacchello F, Scarpa M, et al. High transduction efficiency of human amniotic fluid stem cells mediated by adenovirus vectors. Stem Cells Dev. 2008;17:953-62.

56. Aldridge V, Garg A, Davies N, Bartlett DC, Youster J, Beard H, Kavanagh DP, Kalia N, Frampton J, Lalor PF, Newsome PN. Human mesenchymal stem cells are recruited to injured liver in a beta1-integrin and CD44 dependent manner. Hepatology. 2012;56:1063-73.

57. Eggenhofer E, Benseler V, Kroemer A, Popp FC, Geissler EK, Schlitt HJ, Baan CC, Dahlke MH, Hoogduijn MJ. Mesenchymal stem cells are short-lived and do not migrate beyond the lungs after intravenous infusion. Front Immunol. 2012;3:297.

58. Plitas G, Burt BM, Stableford JA, Nguyen HM, Welles AP, DeMatteo RP. Dendritic cells are required for effective cross-presentation in the murine liver. Hepatology. 2008:47:1343-51.

59. Steinman RM. Dendritic cells in vivo: a key target for a new vaccine science. Immunity. 2008;29:319-24.

60. Jiao J, Sastre D, Fiel MI, Lee UE, Ghiassi-Nejad Z, Ginhoux F, Vivier E, Friedman SL, Merad M, Aloman C. Dendritic cell regulation of carbon tetrachloride-induced murine liver fibrosis regression. Hepatology. 2012;55:244-55

61. Safadi R, Ohta M, Alvarez CE, Fiel Ml, Bansal M, Mehal WZ, Friedman SL. Immune stimulation of hepatic fibrogenesis by CD8 cells and attenuation by transgenic interleukin-10 from hepatocytes. Gastroenterology. 2004;127:870-82.
62. Zhao X, Sun G, Sun X, Tian D, Liu K, Liu T, Cong M, Xu H, Li X, Shi W, et al. A novel differentiation pathway from CD4(+) T cells to CD4(-) T cells for maintaining immune system homeostasis. Cell Death Dis. 2016;7:e2193.

63. Kehren J, Desvignes C, Krasteva M, Ducluzeau MT, Assossou O, Horand F, Hahne M, Kagi D, Kaiserlian D, Nicolas JF. Cytotoxicity is mandatory for CD8(+) T cell-mediated contact hypersensitivity. J Exp Med. 1999:189:779-86.

64. Traidl C, Sebastiani S, Albanesi C, Merk HF, Puddu P, Girolomoni G, Cavani A. Disparate cytotoxic activity of nickel-specific CD8+ and CD4+T cell subsets against keratinocytes. J Immunol. 2000;165:3058-64.

65. Akiba H, Kehren J, Ducluzeau MT, Krasteva M, Horand F, Kaiserlian D, Kaneko F, Nicolas JF. Skin inflammation during contact hypersensitivity is mediated by early recruitment of CD8+T cytotoxic 1 cells inducing keratinocyte apoptosis. J Immunol. 2002;168:3079-87.

66. Nattrass R, Faulkner L, Vocanson M, Antoine DJ, Kipar A, Kenna G, Nicolas JF, Park BK, Naisbitt DJ. Activation of flucloxacillin-specific CD8+T-cells with the potential to promote hepatocyte cytotoxicity in a mouse model. Toxicol Sci. 2015;146:146-56.

67. Mak A, Uetrecht J. The role of CD8 T cells in amodiaquine-induced liver injury in PD1-/ - mice cotreated with anti-CTLA-4. Chem Res Toxicol. 2015;28:1567-73.

68. Caldwell CC, Okaya T, Martignoni A, Husted T, Schuster R, Lentsch AB. Divergent functions of CD4+ T lymphocytes in acute liver inflammation and injury after ischemia-reperfusion. Am J Physiol Gastrointest Liver Physiol. 2005;289:G969-76.

69. Zwacka RM, Zhang Y, Halldorson J, Schlossberg H, Dudus L, Engelhardt JF. CD4(+) T-lymphocytes mediate ischemia/reperfusion-induced inflammatory responses in mouse liver. J Clin Invest. 1997;100:279-89.

70. Aggarwal S, Pittenger MF. Human mesenchymal stem cells modulate allogeneic immune cell responses. Blood. 2005;105:1815-22.

71. Lee VW, Wang YM, Wang YP, Zheng D, Polhill T, Cao Q, Wu H, Alexander IE, Alexander SI, Harris DC. Regulatory immune cells in kidney disease. Am J Physiol Renal Physiol. 2008;295:F335-42.

72. Sennello JA, Fayad R, Morris AM, Eckel RH, Asilmaz E, Montez J, Friedman JM, Dinarello CA, Fantuzzi G. Regulation of T cell-mediated hepatic inflammation by adiponectin and leptin. Endocrinology. 2005:146:2157-64.

73. Ye Z, Wang Y, Xie HY, Zheng SS. Immunosuppressive effects of rat mesenchymal stem cells: involvement of CD4+ CD25+ regulatory T cells. Hepatobiliary Pancreat Dis Int. 2008;7:608-14.

74. Speletas M, Argentou N, Germanidis G, Vasiliadis T, Mantzoukis K, Patsiaoura K, Nikolaidis P, Karanikas V, Ritis K, Germenis AE. Foxp3 expression in liver correlates with the degree but not the cause of inflammation. Mediators Inflamm. 2011;2011:827565.

75. Himmel ME, Yao Y, Orban PC, Steiner TS, Levings MK. Regulatory T-cell therapy for inflammatory bowel disease: more questions than answers. Immunology. 2012;136:115-22.

76. Hou X, Song J, Su J, Huang D, Gao W, Yan J, Shen J. CD4(+) Foxp3(+) Tregs protect against innate immune cell-mediated fulminant hepatitis in mice. Mol Immunol. 2015;63:420-7.

\section{Submit your next manuscript to BioMed Central and we will help you at every step:}

- We accept pre-submission inquiries

- Our selector tool helps you to find the most relevant journal

- We provide round the clock customer support

- Convenient online submission

- Thorough peer review

- Inclusion in PubMed and all major indexing services

- Maximum visibility for your research

Submit your manuscript at www.biomedcentral.com/submit
BioMed Central 